\section{Martyntsev V., Guzii 5. Nazarenko I., Glyva V., Guzii 0.}

\title{
INVESTIGATION OF RHEO- MECHANICAL PROPERTIES OF CEMENT SUSPENSIONS ACTIVATED IN A HYDRODYNAMIC CAVITATOR
}

Наведено результати рео-механічних властивостей цементних суспензій, активованих в гідродинамічному кавітаторі. Відзначено, що зі збільшенням часу кавітачійної обробки від 1 до 25 хв при швидкості потоку до 66,5 м/с при числі кавітащї $X=0,088$, відзначається зростання тиску до 3 МПа і температури до $58^{\circ} \mathrm{C}$. Слід зазначити, що зниження кількості портландиемен-

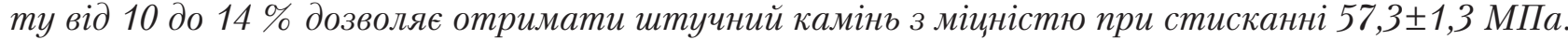

Ключові слова: гідродинамічний кавітатор, динамічна в’язкість, кавітачійна обробка, мічність при стисненні, цементно-водна суспензія.

\section{Introduction}

According to the data of [1], one of the most important stages of concrete formation determining the quality of manufactured building products is the preparation of concrete mixtures. Any technology that allows to save components of concrete mixtures, excluding or simplifying any technological operations for their preparation, makes it possible to reduce financial costs or at the same costs to increase the amount of construction.

At present, along with the chemical modification of Portland cement systems by introducing organic and mineral additives in them, methods of physical treatment of mixing water are being intensively developed [2-4] (Fig. 1). The latter is due to the fact that the water present in the concrete mix is its most active component [5-7]. Forming physical and chemical bonds and adsorption contacts, water sets the speed and depth of hydration of cement, the conditions for the formation and hardening of cement stone, the speed at which concrete strength is set, which ultimately affect the cost of building structures [6, 7].

In turn, it is known that the activity of water depends on its energy state and various physical impacts on water, which intensify the processes taking place with its participation $[8,9]$.

In particular, magnetic, electromagnetic or acoustic treatment of water leads to a change in its ionic composition, the value of the hydrogen ion activity index, viscosity, surface tension and specific electric conductivity [10-13].

At the same time, water acquires a high chemical and hydration activity, which results in the possibility of directed regulation of technological properties of cement systems that are closed with its use. Therefore, it is important to study the activated cement-water suspension with the calculated amount of Portland cement for rheo-mechanical properties, both of the suspensions and of the artificial stone based on them.

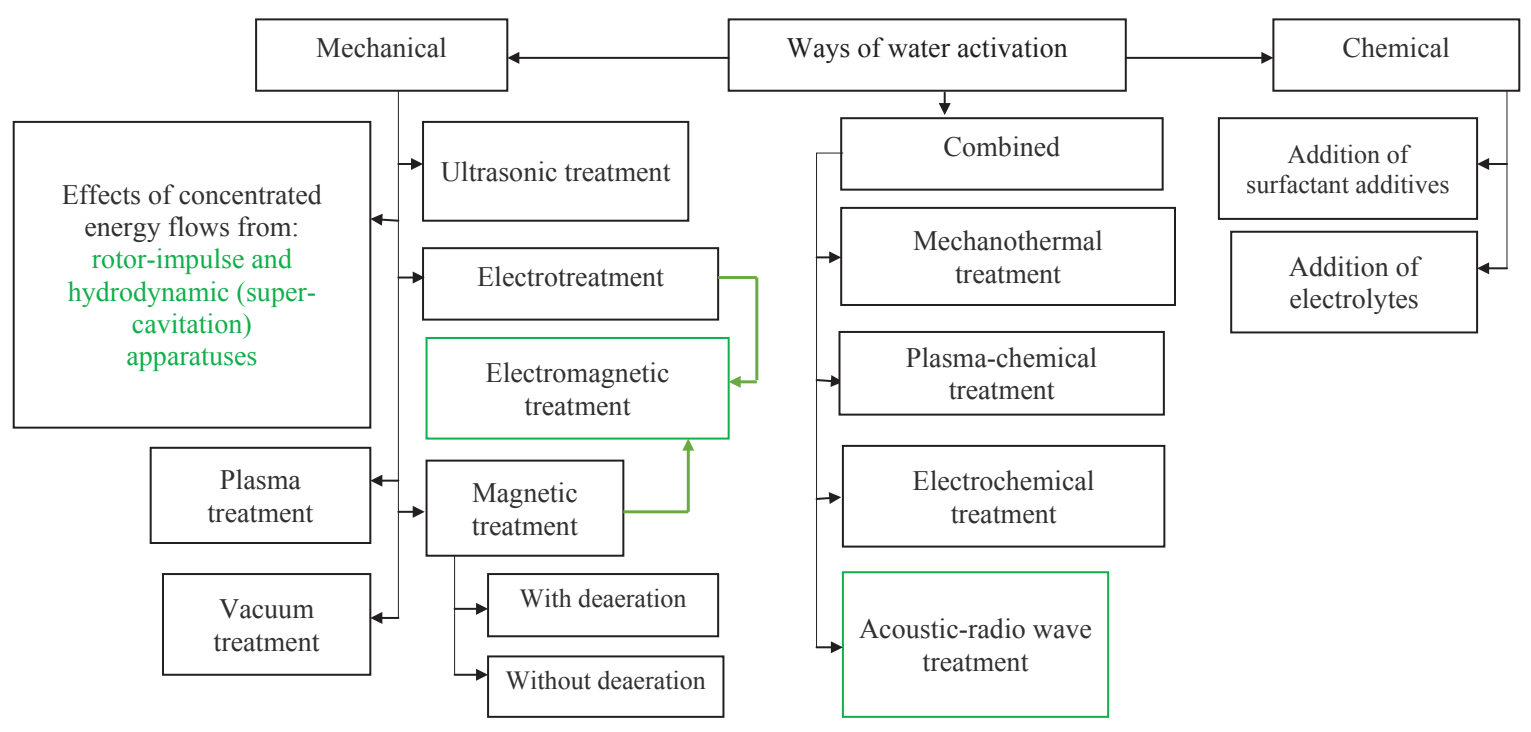

Fig. 1. Methods of activation of mixing water [7]. More modern varieties of physical influences are highlighted in green [8-10] 


\section{The object of research and its technological audit}

The object of research is cement slurries activated in a hydrodynamic cavitator.

For research in this paper used:

- drinking water (DSTU 7525:2014);

- Portland cement of the mark ПЦ I-500-H (DSTU B V.2.7-46:2010), ground to a specific surface of $3550 \mathrm{~cm}^{2} / \mathrm{g}$ (according to Blaine), containing clinker minerals, mass. \%: $\mathrm{C}_{3} \mathrm{~S}-61.2 ; \beta-\mathrm{C}_{2} \mathrm{~S}-15.18 ; \mathrm{C}_{3} \mathrm{~A}-6.45 ; \mathrm{C}_{4} \mathrm{AF}-11.8 ;$

- Dniprovsky sand with a grain size unit $M_{s}=1.47$, an average density of $1420 \mathrm{~kg} / \mathrm{m}^{3}$, a void of $42 \%$, a true density of $2.63 \mathrm{~g} / \mathrm{cm}^{3}$, a clay content of $1.6 \%$.

Total balance on the sieve No. $063-4.5 \%$ by weight. The quality of the sand corresponds to the requirements of DSTU B V.2.7-32-95, DSTU B V.2.7-43-96 to the small aggregate for heavy concrete.

The properties of activated water in conditions of hydrodynamic influences and cement mixtures on their basis have been studied separately. However, there is no data on the influence of the cavitation parameters on the properties of cement slurries and concrete on their basis.

Positive from the use of cavitation effects is the reduction of the dynamic viscosity of cement slurries, the establishment of optimal mixing speed and increased strength properties of the binding agent.

The negative moment in applying cavitation effects is increasing the abrasive wear of the cavitator homogenizer, as well as the lifetime of the activated cement-water slurry.

\section{The aim and objectives of research}

The aim of research is investigation of the parameters of cavitation treatment for the rheo-mechanical properties of cement suspensions.

To achieve this aim, the following tasks are solved:

1. To perform cavitation treatment of water and establish the optimum time of cavitation effect on changes in $\mathrm{pH}$ of water and strength of cement stone.

2. To determine the minimum viscosity and the optimum rate of its achievement in the cement slurry activated in the hydrodynamic cavitator.

3. To determine the strength properties of cement-sand mixtures obtained on the basis of an activated cementwater suspension.

\section{Research of existing solutions of the problem}

As shown by the analysis of literature sources [13-18], the physical activation of water, including hydrodynamic, leads to the formation of hydrated electrons:

$$
\begin{aligned}
& \mathrm{H}_{2} \mathrm{O} \rightarrow \mathrm{H}^{\bullet}+\mathrm{OH}^{\bullet} ; \\
& \mathrm{H}^{\bullet}+\mathrm{H}^{\bullet} \rightarrow \mathrm{H}_{2} ; \\
& \mathrm{H}^{\bullet}+\mathrm{OH}^{\bullet} \rightarrow \mathrm{H}_{2} \mathrm{O} ; \\
& \mathrm{OH}^{\bullet}+\mathrm{OH}^{\bullet} \rightarrow \mathrm{H}_{2} \mathrm{O}_{2} ; \\
& \mathrm{OH}^{\bullet}+\mathrm{H}_{2} \rightarrow \mathrm{H}_{2} \mathrm{O}+\mathrm{H}^{\bullet} ; \\
& \mathrm{H}^{\bullet}+\mathrm{OH}^{-} \rightarrow e_{a q}^{-}+\mathrm{H}_{2} \mathrm{O} ; \\
& e_{a q}^{-}+\mathrm{H}^{+} \rightarrow \mathrm{H}^{\bullet} ; \\
& e_{a q}^{-}+\mathrm{O}_{2} \rightarrow \mathrm{O}_{2}^{-},
\end{aligned}
$$

contributing to an increase in its $\mathrm{pH}$ and, as a consequence, its activity in the case of use as a mixing fluid for cement systems.

Known methods of increasing the activity of cements include mechanochemical, the essence of which is increase in the specific surface area of materials with a simultaneous increase in surface energy, which provides an increase in the reactivity of the cement binder. The disadvantages of the dry method of activating cement include:

- treatment time, reaching up to several hours,

- high energy intensity of equipment and its low productivity,

- short terms and complexity of storage of activated cement [19].

More effective is cavitation treatment of cement-water suspension in thermodynamic or hydrodynamic dispersing activators (cavitators) integrated into the technological process of preparation of concrete mixtures [20].

The principle of operation of cavitation plants is creation of effects of hydrodynamic and acoustic cavitation in a liquid medium passing through the working parts of the unit, when the resulting ultrasonic acoustic vibrations disperse and activate the material particles. The intensive influence on the cement-water suspension of micro-impacts, cavitation ruptures, stretching and ultrasonic vibration leads to its heating, grinding of the particles of the dispersed phase and the formation of stable activated suspensions.

According to the data of [21], the activation treatment of Portland cement by activating the cement binder in hydrodynamic dispersants contributes not only to an increase in the strength of the cement stone by a factor of 2, but also improves the homogeneity of the cementwater suspension.

However, in the above studies there are no data on the effect of cavitation treatment of cement-water suspensions on the $\mathrm{pH}$ change and their viscosity. This shortcoming will be partially disclosed in this paper.

\section{Methods of research}

Activation of mixing water and water-cement suspensions is carried out in a hydrodynamic cavitator (Fig. 2) [15, 22-26], the constructive scheme of which is shown in Fig. 3.

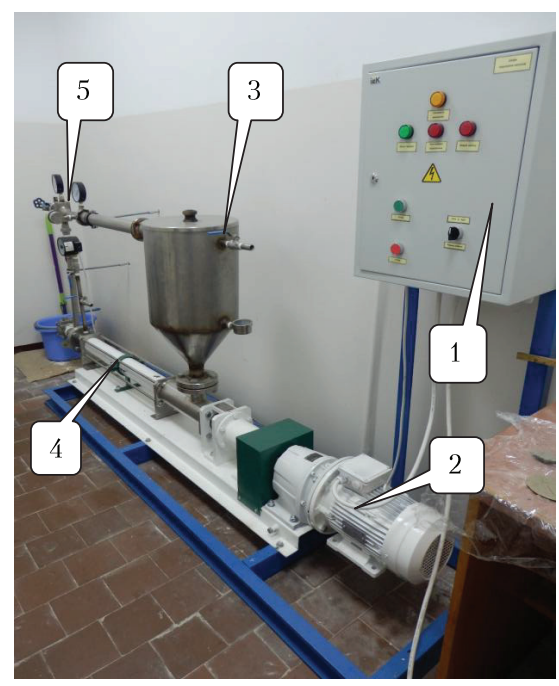

Fig. 2. Hydrodynamic cavitator: 1 - control panel; 2 - motor-reducer; 3 - reactor; 4 - screw pump; 5 - homogenizer 


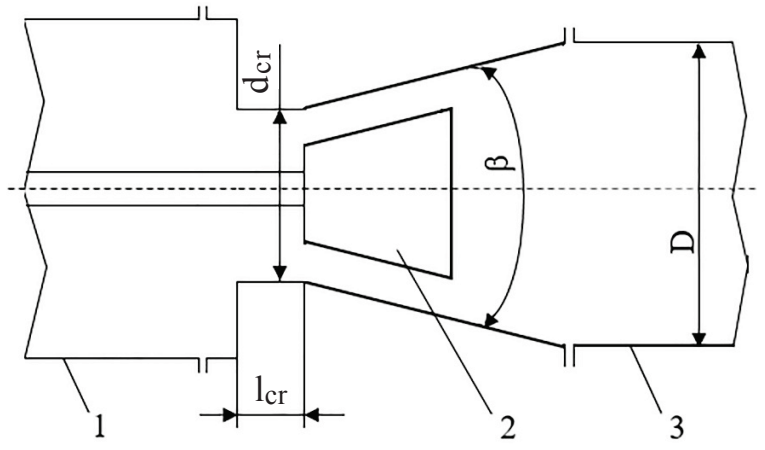

Fig. 3. Constructive scheme of the cavitator:

1 - inlet pipeline; 2 - oscillator - cavitator: $D_{c r}=35 \mathrm{~mm} ; \beta=20^{\circ}$;

$D=4 d_{c r} ; I_{c r}=0.6 . .2 d_{c r} ; 3-$ output pipeline; $c r-$ the critical section

Calculation of the cavitation number with the definition of cavitation treatment is carried out according to the formula:

$$
\chi=\frac{2\left(P-P_{S}\right)}{\rho v^{2}},
$$

where $P$ - pressure of the flow, $\mathrm{Pa} ; P_{s}$ - saturated vapor pressure, $\mathrm{Pa} ; \rho$ - density of water and cement-water suspension, $\mathrm{kg} / \mathrm{m}^{3} ; v$ - flow velocity at the nozzle inlet, $\mathrm{m} / \mathrm{s}$.

The processes of dispersion and amorphization of the structure of the solid phase of the cement slurry are determined by the acoustic emission method [27-29] (Fig. 4).

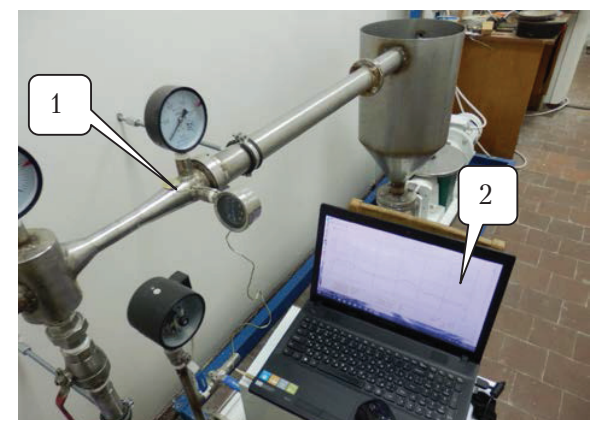

Fig. 4. Equipment for fixing and digital recording of noise arising in the cavitator homogenizer: 1 - broadband piezoceramic acoustic sensor; 2 - notebook with Spectrogram 16 software

Digital audio recording of noise arising during cavitation treatment of mixing water and cement slurry is carried out in WAV format of the Spectrogram program 16.

A continuous spectrum of acoustic noise carries information about physical phenomena that occur in the flow of fluid passing through the cavitator [28]. With increasing hydrodynamic pressure, a more intensive collapse of cavitation bubbles occurs, contributing to an increase in the noise intensity. Spectrograms record bursts of noise characterizing the dispersion of cement particles in the suspension flow.

The linear dependence of the flow velocity on noise is described by the dependence:

$$
v=0.015 N+1.7
$$

where

$$
N=10 \lg \left(I / I_{0}\right),
$$

where $I_{0}=10-12 \mathrm{~W} / \mathrm{m}^{2}$ - the power of the sound wave through a unit of surface relative to the input level.

The intensity of the sound resulting from the collapse of cavitation bubbles is described by the dependence:

$$
I=\frac{\Delta p_{0}^{2}}{2 r v}
$$

where $\Delta p_{0}$ - the amplitude of the sound wave expressed in the number of decibels $N ; v$ - the velocity of the sound wave that propagates in the cement slurry; $\rho$ - the density of the cement slurry.

$\mathrm{PH}$ changes before and after cavitation treatment of water and cement suspensions are carried out on the EZODO PL-700AL multifunction laboratory instrument (Taiwan), combining the functions of a $\mathrm{pH}$ meter/ORP meter/Oximeter/Conductometer/Salinometer/Thermometer.

The rheological properties of the cement slurries are determined using a Brookfield viscometer RV DV2T (USA), spindle No. 4 (Fig. 5).

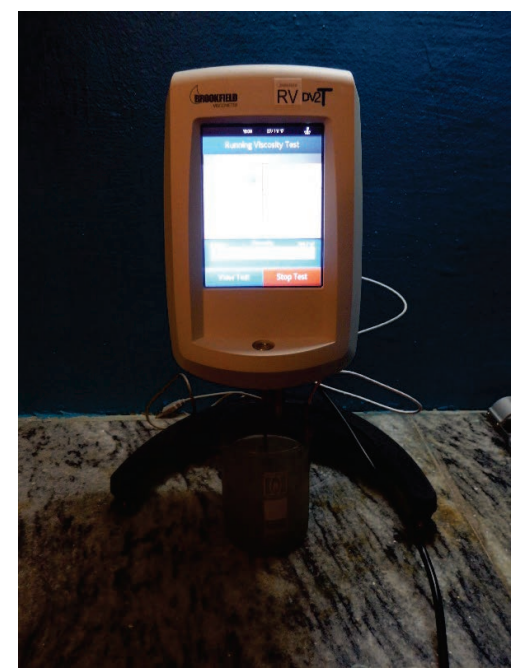

Fig. 5. Brookfield viscometer RV DVZT

Physical and mechanical tests of Portland cement pre carried out in accordance with GOST B.2.7-185: 2009, DSTU B V.2.7-187:2009, DSTU B V.2.7-188:2009, which covered the definitions of normal density of cement paste, setting time, tensile strength compression and bending of cement stone.

\section{Research results}

Activation of water is carried out in a static-type hydrodynamic cavitator (Fig. 2). The water is subjected to cavitation for 25 minutes and the controlled parameters are fixed at the intervals specified by the experiment. The results of measurements are given in Table 1 .

With an interval of 5 minutes, the activated water is poured into a container, which is subsequently used to form cement-sand samples (Table 2).

It can be seen from the spectrogram (Fig. 6, $a$ ) that at the end of the first minute of cavitation treatment of the mixing water at a pressure of $0.5 \mathrm{MPa}$, a burst of noise at a frequency of $23 \mathrm{kHz}$ is recorded characterizing the beginning of the process of dispersing impurities in water and breaking the Van der Waals bonds. With an increase 
in the time of cavitation treatment from 1 to 25 minutes at a flow rate of $66.5 \mathrm{~m} / \mathrm{s}$ and a cavitation number of $X=0.088$, pressure increases to $3 \mathrm{MPa}$ and a temperature of up to $58{ }^{\circ} \mathrm{C}$. Spectrograms (Fig. 6, $b$ ) show bursts of noise amplitudes at frequencies of $500 \mathrm{~Hz}, 1$ and $4 \mathrm{kHz}$, which characterize the avalanche increase in the products of water thermolysis with a simultaneous increase in the $\mathrm{pH}$ of water to 8.25 (Fig. 7).

Table 1

Controlled water activation parameters

\begin{tabular}{|c|c|c|c|}
\hline $\begin{array}{c}\text { Duration of } \\
\text { cavitation treat- } \\
\text { ment, min }\end{array}$ & $\begin{array}{c}\text { Pressure at the } \\
\text { inlet to the cavi- } \\
\text { tator P1, MPa }\end{array}$ & $\begin{array}{c}\text { Temperature at the } \\
\text { outlet from the flow } \\
\text { chamber of the } \\
\text { cavitator T1, }{ }^{\circ}\end{array}$ & $\begin{array}{c}\text { Temperature } \\
\text { in the reactor } \\
\text { T2, }{ }^{\circ}\end{array}$ \\
\hline 1 & 0.5 & 22 & 21 \\
\hline 4 & 1.1 & 25 & 23 \\
\hline 6 & 1.3 & 29 & 26 \\
\hline 10 & 1.4 & 33 & 30 \\
\hline 13 & 1.5 & 40 & 36 \\
\hline 15 & 1.8 & 42 & 37 \\
\hline 20 & 2.1 & 45 & 40 \\
\hline 23 & 2.2 & 50 & 44 \\
\hline 24 & 2.5 & 52 & 45 \\
\hline 25 & 3 & 58 & 50 \\
\hline
\end{tabular}

The calculated energy, which is released as a result of the collapse of cavitation bubbles, $\left(E s=1046.29 \cdot 10^{-6} \mathrm{~J}\right)$ under the above modes of cavitation influences can break the $\mathrm{O}-\mathrm{H}$ bond $\left(E s=71.63 \cdot 10^{-20} \mathrm{~J}\right)[16,24,30-32]$.

The observed increase in the $\mathrm{pH}$ of water, regardless of the sources of physical effects, is confirmed by the data of [14-17]. From the data of Table 2 it is shown that the time of cavitation treatment of water affects the physical and mechanical properties of cement-sand mixtures, namely:

- the value of NDD increases by $1 \%$;

- there is an increase in the mobility of the mixture (cone flow) in 1.13...1.21 times in comparison with the control composition;

- the start time of the setting is within the experimental error;

- in the early periods of hardening, a slight decrease in the strength characteristics of cement-sand mixtures on activated water is observed compared with the control composition;

- at the brand age the strength values are higher by 1.11...1.14 times compared to the brand strength of the control sample.

Taking into account the positive tendency of growth of brand strength of cement on activated water, further studies are aimed at activating water-cement suspensions, including up to $10 \%$ of cement in the suspension. The results of the studies are given in Table 3 .
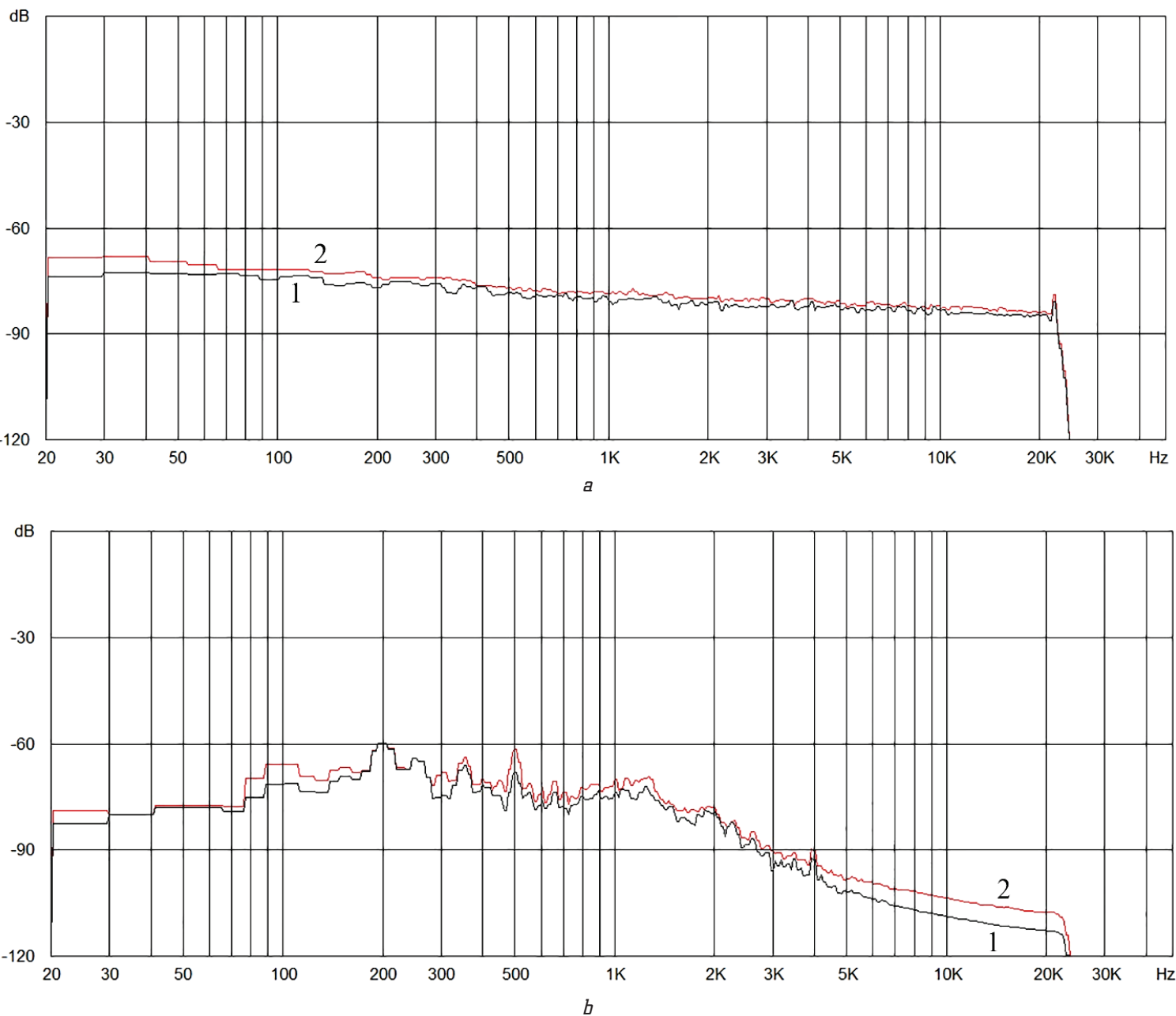

Fig. 6. Spectrogram of acoustic noise: $a$ - first; $b$ - at the end of the cavitation treatment of water: amplitude swings - 1 (min), 2 (max) 


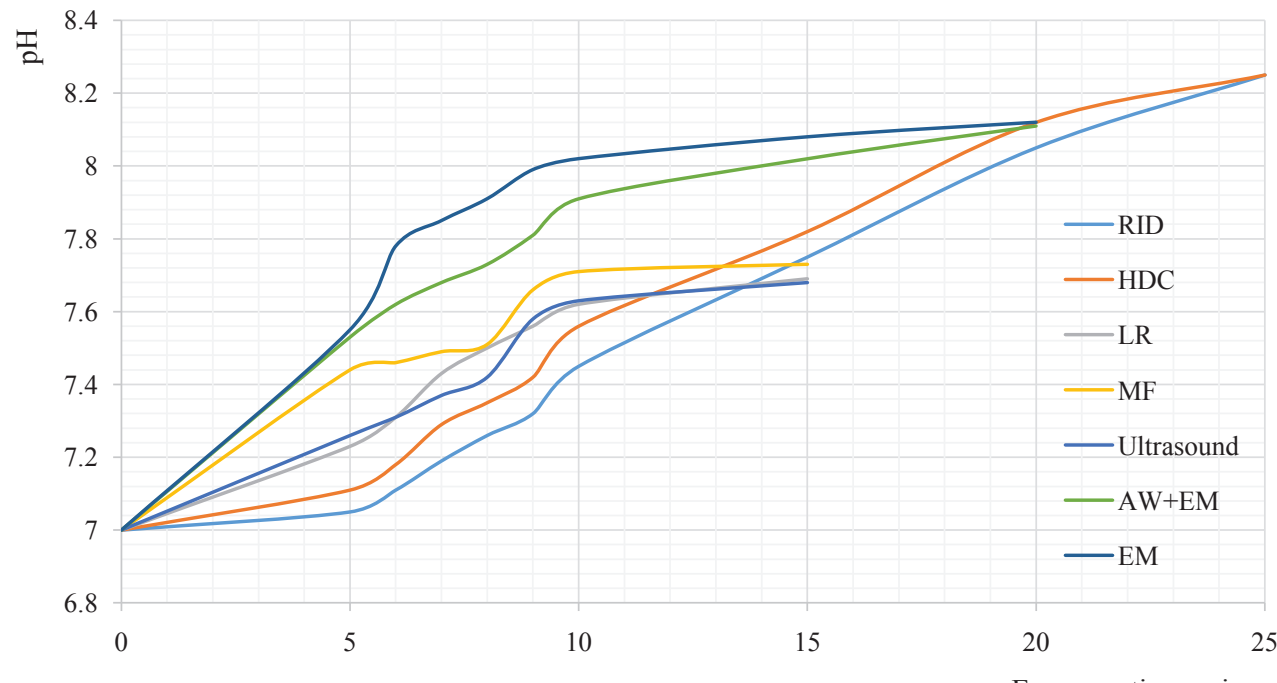

Exposure time, min

Fig. 7. Change in water $\mathrm{pH}$ depending on the time of energy impacts and the type of devices: RID - rotary impulse device; HDC - hydrodynamic cavitator; LR - laser radiation; MF - magnetic field; AW + EM - jointly acoustic-wave with electromagnetic; EM - electromagnetic

Table 2

Test results of cement-sand mixtures on activated water $(W / L=0.5=$ const

\begin{tabular}{|c|c|c|c|c|c|c|}
\hline \multirow{2}{*}{$\begin{array}{c}\text { Activation } \\
\text { time, min }\end{array}$} & \multirow{2}{*}{$\begin{array}{c}\text { NDD, } \\
\%\end{array}$} & \multirow{2}{*}{$\begin{array}{c}\text { Cone } \\
\text { flow, } \\
\text { mm }\end{array}$} & \multirow{2}{*}{$\begin{array}{c}\text { Start of } \\
\text { setting, } \\
\text { min }\end{array}$} & \multicolumn{3}{|c|}{$\begin{array}{c}\text { Rcs/Rcf, MPa, depending on the } \\
\text { hardening time, days }\end{array}$} \\
\cline { 5 - 8 } & & 2 & 7 & 28 \\
\hline 0 & 28 & 120 & 111 & $20.5 / 2.7$ & $38.51 / 4.8$ & $51.4 / 5.2$ \\
\hline 5 & 29 & 140 & 95 & $19.8 / 2.7$ & $35.0 / 4.8$ & $58.8 / 5.6$ \\
\hline 10 & 29 & 145 & 113 & $19.4 / 2.9$ & $35.0 / 4.9$ & $58.4 / 5.3$ \\
\hline 15 & 29 & 145 & 108 & $19.7 / 2.7$ & $34.1 / 4.7$ & $56.3 / 5.4$ \\
\hline 20 & 29 & 135 & 114 & $19.4 / 3.0$ & $34.1 / 4.8$ & $55.3 / 5.5$ \\
\hline 25 & 29 & 145 & 110 & $20.0 / 2.9$ & $36.3 / 4.9$ & $54.4 / 5.5$ \\
\hline
\end{tabular}

Table 3

Controlled parameters of activation of water-cement suspensions

\begin{tabular}{|c|c|c|c|}
\hline $\begin{array}{c}\text { Duration of } \\
\text { cavitation treat- } \\
\text { ment, min }\end{array}$ & $\begin{array}{c}\text { Pressure at the } \\
\text { inlet to the cavita- } \\
\text { tor } P, \mathrm{MPa}\end{array}$ & $\begin{array}{c}\text { Temperature at the } \\
\text { outlet from the flow } \\
\text { chamber } T 1,{ }^{\circ} \mathrm{C}\end{array}$ & $\begin{array}{c}\text { Temperature } \\
\text { in the reactor } \\
T 2,{ }^{\circ} \mathrm{C}\end{array}$ \\
\hline 5 & 0.55 & 26 & 23 \\
\hline 10 & 0.63 & 32 & 28 \\
\hline 15 & 0.65 & 35 & 32 \\
\hline
\end{tabular}

As can be seen from the data in Table 3, an increase in the time of cavitation treatment helps to increase the pressure and temperature at the outlet of the slurry from the flow chamber. This indicates the passage of more intensive dispersing processes in the frequency range of $700-800 \mathrm{~Hz}$ and mass-transfer processes in the frequency range $1.9-3.5 \mathrm{kHz}$ (Fig. 8), aimed both at reducing the size of Portland cement particles and on the formation of primary crystallization structures. The beginning of amorphization of clinker minerals is fixed at a frequency of the order of $17 \mathrm{kHz}$ for 5 and $10 \mathrm{~min}$ of cavitation treatment (Fig. 8, $a, b$ ). It is impossible to judge the development of this process due to the limited frequency of the computer's sound card.
Cavitation treatment of water-cement suspension for more than 15 minutes (Fig. 8,c) is not practical, since its temperature rises, as a result of which the rate of crystallization increases and slurry thickens. This is confirmed by rheological studies (Fig. 9).

As can be seen from Fig. 9, the non-activated watercement slurry refers to pseudo-plastic fluids, i. e., reduces its viscosity from $451.000 \mathrm{cP}$ to $1279 \mathrm{cP}$ while increasing the spindle rotation speed from 0.1 to $75 \mathrm{~min}^{-1}$. The water-cement suspension activated for 10 minutes refers to the dilatant liquids, i. e., increases its viscosity from 160 to $273.5 \mathrm{cP}$ with an increase in the spindle rotation speed from 50 to $200 \mathrm{~min}^{-1}$.

In general, the studied cement-water suspension refers to thixotropic liquids and, when applied externally, for example vibration, becomes a viscous-fluid state [33]. However, the removal of a complete rheological pattern is difficult due to the intensive sedimentation of the solid phase (cement particles) in the liquid phase of the suspension.

Elimination of this disadvantage is possible due to the introduction of stabilizer additives, for example starch esters.

Table 4 shows the results of physical and mechanical tests of cement-sand mixtures obtained on the basis of a $10 \%$ cement-water suspension activated for $11 \mathrm{~min}$. Unlike the traditional scheme of preparation of cementsand mixtures, the approach is based on the following:

- first, the missing amount of cement is added taking into account the one that is already in the activated cement-water suspension;

- secondly, they followed the path of reducing the amount of cement in the investigated system. Formulations of mixtures: No. $1-W-247.5 \mathrm{ml} ; C-0.45 \mathrm{~kg}$; $S-1.35 \mathrm{~kg} ;$ No. $2-W-242 \mathrm{ml} ; C-0.44 \mathrm{~kg}$; $S-1.35 \mathrm{~kg} ;$ No. $3-W-236.5 \mathrm{ml} ; C-0.43 \mathrm{~kg}$; $S-1.35 \mathrm{~kg}$.

From the obtained test results follows: the water consumption of the mixtures has increased insignificantly (by $0.5 \%$ ), the cone flow has increased considerably by 1.33...1.38 times compared with the unactivated system. In 1.14 imes in comparison with the activated water of mixing. 

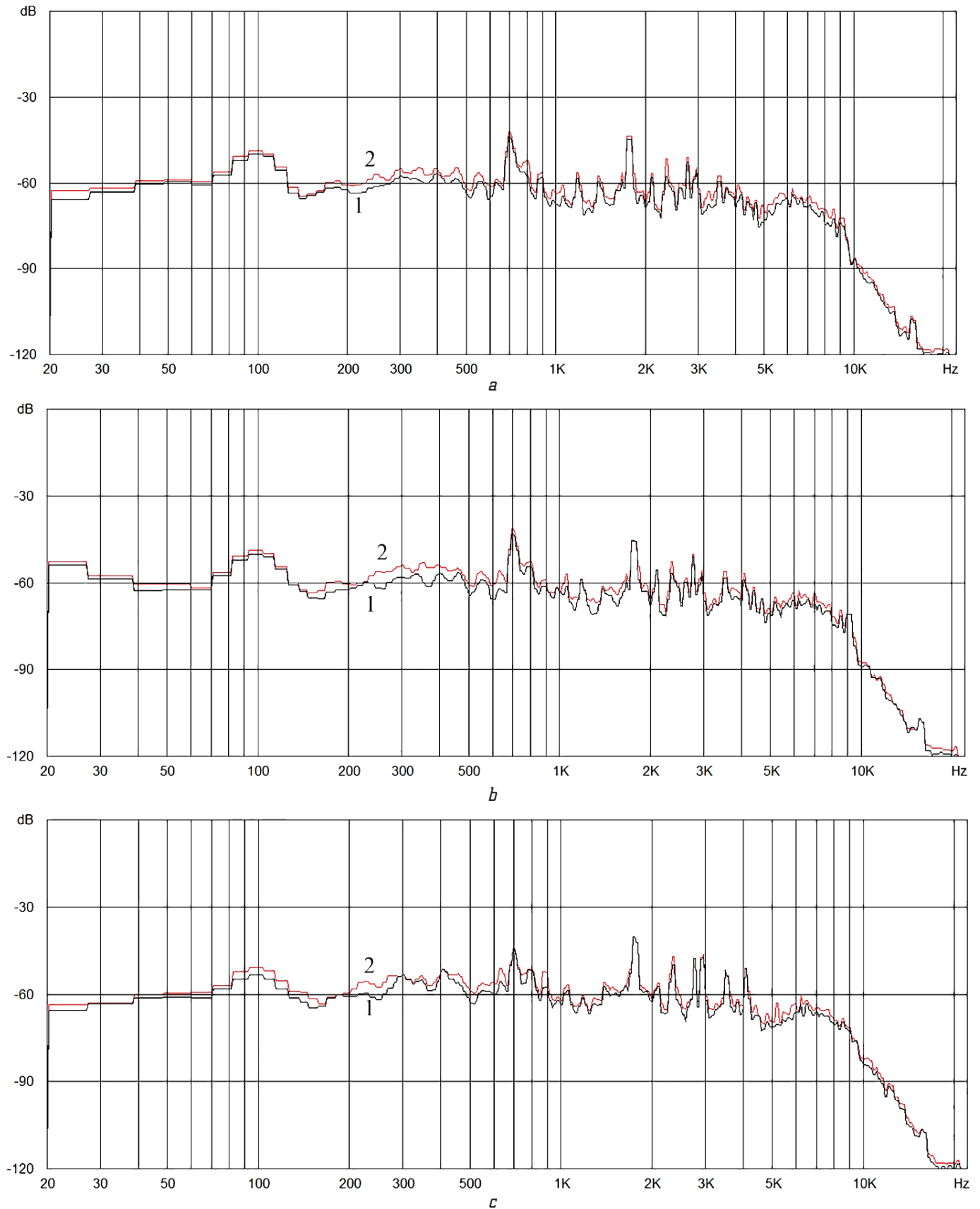

Fig. 8. Spectrogram of acoustic noise after:

a - 5 min; $b-10$ min; $c-15$ min of cavitation treatment of water-cement suspensions: amplitude range - 1 (min), 2 (max)

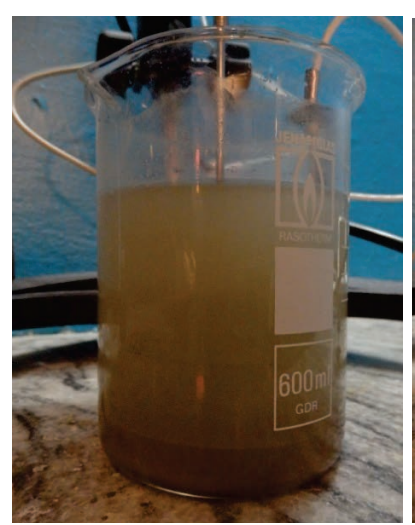

a

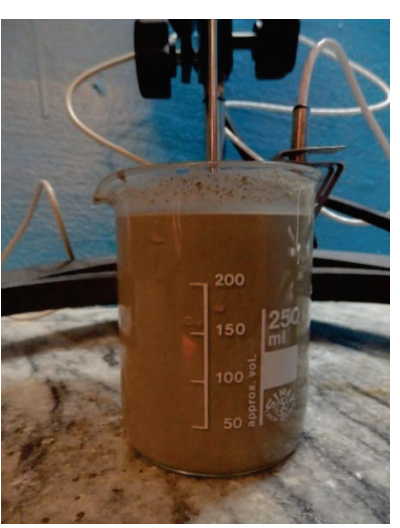

b

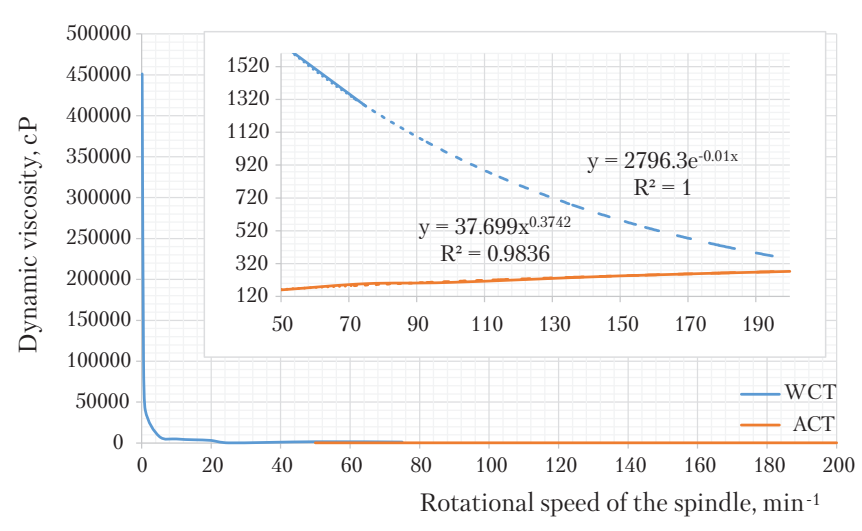

c

Fig. 9. Change in viscosity of $10 \%$ cement-water suspension, depending on the ratational speed of the spindle: $a$ - without cavitation treatment; $b$ - after cavitation treatment; $c$ - rheological flow curves 
Table 4

The results of tests of cement-sand mixtures on an activated $10 \%$ cement-water suspension $(W / C=0.55=$ const $)$

\begin{tabular}{|c|c|c|c|c|c|c|}
\hline \multirow{2}{*}{$\begin{array}{c}\text { Cement } \\
\text { consump- } \\
\text { tion, kg }\end{array}$} & $\begin{array}{c}\text { Cone } \\
\text { flow, } \\
\text { mm }\end{array}$ & $\begin{array}{c}\text { Start of } \\
\text { setting, } \\
\text { min }\end{array}$ & \multirow{2}{*}{$\begin{array}{c}N D D, \\
\%\end{array}$} & \multicolumn{3}{|c|}{$\begin{array}{c}\text { Rcs/Rcf, MPa, depending on the } \\
\text { hardening time, days }\end{array}$} \\
\cline { 5 - 7 } & & 2 & 7 & 28 \\
\hline 0.45 & 160 & 105 & 29.5 & $20.1 / 2.4$ & $32.0 / 4.5$ & $58.5 / 6.9$ \\
\hline 0.44 & 165 & 115 & 29.5 & $20.6 / 2.5$ & $33.3 / 4.6$ & $57.3 / 6.7$ \\
\hline 0.43 & 160 & 103 & 29.5 & $19.8 / 2.3$ & $34.8 / 4.7$ & $56.0 / 6.5$ \\
\hline
\end{tabular}

The compressive strength on the 28th day of hardening increased 1.14 times as compared to the unactivated cement system and remained at the strength level of astringents obtained on the activated water of mixing. It should be noted that reducing the amount of Portland cement from 10 to $14 \%$ makes it possible to obtain an artificial stone with a compressive strength of $57.3 \pm 1.3 \mathrm{MPa}$.

\section{SWOT analysis of research results}

Strengths. The positive effect of cavitation treatment on both the activation of water of mixing and on the activation of cement-water suspensions is noted. It is noted that at 10 minutes of cavitation treatment at pressures of $0.63-1.4 \mathrm{MPa}$ :

- $\mathrm{pH}$ of the medium increases $(\mathrm{pH}+7.56)$;

- the dynamic viscosity of suspensions decreases in 10.38 times;

- the brand strength of the studied binding compositions increases in $1.14 \ldots 1.38$ times.

Weaknesses. The negative effect of the object of research on its internal factors is manifested in the retardation of the kinetics of the set of strength in the early stages of hardening on days 2 and 7 .

Opportunities. Opportunities for further research will be directed at studying the processes of structure formation of activated cement-water suspensions, improving the design of the cavitator and the mixing chamber for increasing the flow rates, enhancing physical effects.

The introduction of the research facility into production will facilitate the production of more homogeneous concrete mixtures and quality products based on them.

Threats. The external field, as well as the limited frequency of the sound card of the computer, can affect the object of research, which will be taken into account in further research. The proposed way to activate binders relates to nanotechnology and will initially be costly for the construction industry. However, the payback of this technology will begin to appear in 1.5 years from the introduction.

In the world there is a sufficient variety of cavitation devices, but the investigated one belongs to the category of supercavitational mixers, in which physicochemical processes are carried out in the cavitation cavity, but not in the near-wall regions typical for simpler cavitator designs.

\section{Conclusions}

1. After cavitation treatment of mixing water at a pressure of $0.5 \mathrm{MPa}$, a burst of noise at a frequency of $23 \mathrm{kHz}$ is recorded characterizing the beginning of the process of dispersion of impurities in water and the breakdown of Van der Waals bonds. With an increase in the time of cavitation treatment from 1 to 25 minutes at a flow rate of up to $66.5 \mathrm{~m} / \mathrm{s}$ with a cavitation number of $X=0.088$, there is a pressure increase of up to $3 \mathrm{MPa}$ and a temperature of up to $58{ }^{\circ} \mathrm{C}$. The fixed bursts of noise amplitudes at frequencies of $500 \mathrm{~Hz}, 1$ and $4 \mathrm{kHz}$, characterize the avalanche-like increase in the products of water thermolysis with a simultaneous increase in its $\mathrm{pH}$ to 8.25 . Brand strength of cement stone is 1.14 times higher than the strength of the control composition.

The increase in pressure and temperature in the cementwater suspension contributes to the intensification of the process of dispersion of cement particles in the frequency range $700-800 \mathrm{~Hz}$ and the passage of intensive massexchange processes in the frequency range $1.9-3.5 \mathrm{kHz}$, which promote the formation of primary crystallization structures. The beginning of amorphization of clinker minerals is fixed at a frequency of the order of $17 \mathrm{kHz}$ for 5 and $10 \mathrm{~min}$ of cavitation treatment. It is impossible to judge the development of this process due to the limited frequency of the computer's sound card.

2 . It is found that the non-activated water-cement suspension refers to pseudoplastic fluids, i. e., reduces its viscosity from $451.000 \mathrm{cP}$ to $1279 \mathrm{cP}$ when the spindle rotation speed is increased from 0.1 to $75 \mathrm{~min}^{-1}$. The water-cement suspension activated for 10 minutes refers to the dilatant liquids, i. e., increases its viscosity from 160 to $273.5 \mathrm{cP}$ with an increase in the spindle rotation speed from 50 to $200 \mathrm{~min}^{-1}$.

3 . It is shown that cavitation treatment of cementwater suspensions promotes an increase in brand strength of 1.14 times in comparison with an unactivated cement system and remained at the strength level of astringents obtained on activated water by mixing. It should be noted that reducing the amount of Portland cement from 10 to $14 \%$ makes it possible to obtain an artificial stone with a compressive strength of $57.3 \pm 1.3 \mathrm{MPa}$.

\section{Acknowledgement}

The authors would like to acknowledge financial support of the Ministry of Education and Science of Ukraine:

- Research project «Physico-chemical bases for regulation of structure formation process and properties of the mineral alkaline aluminosilicate bond as adhesive for the use in ecologically safety wood products for various use» (Reg. No. 0117U004842);

- Research project «Physicochemical foundations for the creation of geo-cement and coatings on their basis for the protection of concrete from corrosion» (Reg. No. 0115U000332);

- Research project «Development of prescription and technological solutions for the plasticisation of alkaline concrete for road construction with the use of associated products of metallurgy and heat power engineering» (Reg. No. 0116U008073).

\section{References}

1. Ajaronok, V. V. Akusto-radiovolnovaia aktivatsiia vody zatvoreniia portlandtsementnyh sistem [Text] / V. V. Ajaronok, S. V. Goncharik, N. I. Chubrik, N. H. Belous, S. P. Rodtsevich, V. D. Koshevar, V. V. Rubanik, O. N. Mahanovskaia, A. I. Orlovich // Elektronnaia obrabotka materialov. - 2011. Vol. 47 , No. 5. - P. $50-59$.

2. Kasatkina, V. I. Vliianie mehanomagnitnoi aktivatsii vodnyh sistem na svoistva betona [Text] / V. I. Kasatkina, S. V. Fedosov, M. V. Akulova // Stroitel'nye materialy. - 2007. - No. 11. P. $58-59$. 
3. Pomazkin, V. A. Fizicheskaia aktivatsiia vody zatvoreniia betonnyh smesei [Text] / V. A. Pomazkin // Stroitel'nye materialy. 2003. - No. 2. - P. 14-16.

4. Pomazkin, V. A. Perspektivnye napravleniia primeneniia magnitnoi aktivatsii [Text] / V. A. Pomazkin, A. A. Makeeva // Vestnik Orenburgskogo gosudarstvennogo universiteta. - 2001. No. 1. - P. 109-114.

5. Taylor, H. F. W. Cement chemistry [Text] / H. F. W. Taylor. Thomas Telford Publishing, 1997. - 459 p. doi:10.1680/cc.25929

6. Ratinov, V. B. Dobavki v beton [Text] / V. B. Ratinov, T. I. Rozenberg. - Moscow: Stroiizdat, 1978. - 190 p.

7. Kudiakov, A. I. Uluchshenie kachestva tsementnogo kamnia putem mnogochastotnoi ul'trazvukovoi aktivatsii vody zatvoreniia [Text] / A. I. Kudiakov, A. G. Petrov, G. G. Petrov, K. V. Ikonnikova // Vestnik TGASU. - 2012. - No. 3. - P. 143-152.

8. Batrakov, V. G. Modifitsirovannye betony [Text] / V. G. Batrakov. - Moscow: Stroiizdat, 1998. - 748 p.

9. Ramachandran, V. S. Concrete Admixtures Handbook, Second Edition: Properties, Science and Technology (Building Materials Science Series) [Text] / V. S. Ramachandran. - William Andrew, 1997. - 1183 p.

10. Dolinskii, A. A. Voda v usloviiah obrabotki putem diskretnoimpul'snogo vvoda energii [Text] / A. A. Dolinskii, Yu. A. Shurchkova // Dopovidi Natsionalnoi akademii nauk Ukrainy. - 2013. No. 9. - P. 93-100.

11. Akopyan, S. N. A study of the specific conductivity of water exposed to constant magnetic field, electromagnetic field, and low-frequency mechanical vibration [Text] / S. N. Akopyan, S. N. Airapetyan // Biophysics. - 2005. - Vol. 50, No. 2. P. 255-259.

12. Stas, I. E. Vliianie vysokochastotnogo elektromagnitnogo polia na fiziko-himicheskie svoistva distillirovannoi vody [Text] I. E. Stas, A. P. Mihailova, A. P. Bessonova // Vestnik Tomskogo gosudarstvennogo universiteta. - 2006. - No. 62. - P. 43-51.

13. Kulagin, V. A. Metody i sredstva tehnologicheskoi obrabotki mnogokomponentnyh sred s ispol'zovaniem effektov kavitatsii [Text]: Thesis of the Doctor of Technical Sciences: 01.04.14, 01.02 .05 / V. A. Kulagin. - Krasnoiarsk, 2004. - 406 p.

14. Margulis, M. A. Osnovy zvukohimii (himicheskie reaktsii v akusticheskih poliah) [Text]: Handbook / M. A. Margulis. Moscow: Vyssha shkola, 1984. - 272 p.

15. Nazarenko, I. Intensification of hydrodynamic cavitation processes for obtaining astringents when preparing concrete mixture [Text] / I. Nazarenko, V. Martyntsev, S. Guzii // MOTROL. Commission of Motorization and Energetics in Agriculture. 2017. - Vol. 19, No 3. - P. 89-93.

16. Vitenko, T. N. Mehanizm aktiviruiushchego deistviia gidrodinamicheskoi kavitatsii na vodu [Text] / T. N. Vitenko, Ya. M. Gumnitskii // Himiia i tehnologiia vody. - 2007. Vol. 29, No. 5. - P. 422-432.

17. Promtov, M. A. Cavitation Treatment for Wastewater Disinfection [Text] / M. A. Promtov, A. V. Aleshin, M. M. Kolesnikova, D. S. Karpov // Vestnik Tambovskogo gosudarstvennogo tehnicheskogo universiteta. - 2015. - Vol. 21, No. 1. P. 105-111. doi:10.17277/vestnik.2015.01.pp.105-111

18. Kirsanov, E. A. Nen'iutonovskoe povedenie strukturirovannyh sistem [Text] / E. A. Kirsanov, V. N. Matveenko. - Moscow: TEHNOSFERA, 2016. - 384 p.

19. Sovalov, I. G. Metody aktivatsii tsementov i vliianie aktivatsii na svoistva betonov [Text] / I. G. Sovaldov. - Moscow: TsBTI NIIOMTP, 1963. - 41 p.

20. Lamekin, N. S. Kavitatsiia: teoriia i primenenie [Text] / N. S. Lamekin. - Moscow: Rusaki, 2000. - 246 p.

21. Zibnitskaia, N. E. Perspektivy aktivirovaniia tsementnyh viazhushchih $\mathrm{v}$ tehnologii betonov [Text] / N. E. Zibnitskaia, D. I. Zhivetev, A. N. Mashkin // Trudy NGASU. - 2005. Vol. 8, No. 2 (32). - P. 87-91.

22. Guzii, S. G. Issledovaniia fizicheskih svoistv shchelochnyh aliumosilikatnyh suspenzii posle kavitatsionnoi obrabotki [Text] / S. G. Guzii, S. A. Terenchuk // Vestnik NTU «HPI». Himiia, himicheskaia tehnologiia ta ekologiia. - 2010. - Vol. 65. P. 119-126.

23. Krivenko, P. V. The Influence of Cavitation Treatment on Nano Structuring of Alkali Aluminosilicate Binder for Intumescent Coatings [Text] / P. V. Krivenko, S. Guzii, R. Hela // Materials Science Forum. - Vol. 908. - P. 63-70. doi:10.4028/ www.scientific.net/msf.908.63
24. Saksena, T. K. Sonoluminescence from Stable Cavitation [Text] / T. K. Saksena, W. L. Nyborg // The Journal of Chemical Physics. 1970. - Vol. 53, No. 5. - P. 1722-1734. doi:10.1063/1.1674249

25. Ozonek, J. Application of Hydrodynamic Cavitation in Environmental Engineering [Text] / J. Ozonek. - London: CRC Press, 2012. - 144 p. doi:10.1201/b11825

26. Krivenko, P. The Influence of Cavitation Treatment on Amorphization of Kaolinite in the Dispersion of the «Kaolin- $\mathrm{Na}_{2} \mathrm{O} \cdot \mathrm{nSiO}_{2} \times$ $\times \mathrm{mH}_{2} \mathrm{O}-\mathrm{NaOH}-\mathrm{H}_{2} \mathrm{O}$ » Composition [Text] / P. Krivenko, S. Guziy, J. Abdullah Al Musa // Calcined Clays for Sustainable Concrete. RILEM Bookseries. - Netherlands: Springer, 2015. - P. 387-393. doi:10.1007/978-94-017-9939-3_48

27. Glyva, V. A. Neperervnyi akustychnyi kontrol ta identyfikatsiia trishchynoutvorennia $\mathrm{v}$ metalevykh konstruktsiiakh [Text] / V. A. Glyva, M. I. Delas, B. M. Yeremenko // Management of Development of Complex Systems. - 2013. - Vol. 15. P. $115-118$.

28. Smirnov, A. I. Generatsiia akusticheskih kolebanii v himicheskih reaktsiiah i fiziko-himicheskih protsessah [Text] / A. I. Smirnov // Rossiiskii himicheskii zhurnal. - 2001. - Vol. 45. - P. 29-34.

29. Semashko, R. A. Akusticheskaia emissiia v eksperimental'nom materialovedenii [Text] / R. A. Semashko, V. I. Shport, B. I. Marin et al.; ed. by N. A. Semashko. - Moscow: Mashinostroenie, 2002. - 240 p.

30. Volkov, A. I. Bol'shoi himicheskii spravochnik [Text] / A. I. Volkov, I. M. Zharskii. - Minsk: Sovremennaia shkola, 2005. - 608 p.

31. Kumar, J. K. Cavitation - a New Horizon in Water Disinfection Water disinfection by ultrasonic and hydrodynamic cavitation [Text] / J. K. Kumar, A. B. Pandit. - Verlag: VDM, 2010. - 304 p.

32. Gogate, P. R. Application of cavitational reactors for water disinfection: Current status and path forward [Text] / P. R. Gogate // Journal of Environmental Management. - 2007. Vol. 85, No. 4. - P. 801-815. doi:10.1016/j.jenvman.2007.07.001

33. Frolov, Yu. G. Kurs kolloidnoi himii [Text] / Yu. G. Frolov. Moscow: Himiia, 1982. - 400 p.

\section{ИССЛЕДОВАНИЕ РЕО-МЕХАНИЧЕСКИХ СВОЙСТВ ЦЕМЕНТНЫХ СУСПЕНЗИЙ, АКТИВИРОВАННЫХ В ГИДРОДИНАМИЧЕСКОМ KABИTATOPE}

Приведены результаты рео-механических свойств цементных суспензий, активированных в гидродинамическом кавитаторе. Отмечено, что с увеличением времени кавитационной обработки от 1 до 25 мин при скорости потока до 66,5 м/с при числе кавитации $X=0,088$, отмечается рост давления до $3 \mathrm{MПа}$ и температуры до $58{ }^{\circ} \mathrm{C}$. Следует отметить, что снижение количества портландцемента от 10 до 14 \% позволяет получить искусственный камень с прочностью при сжатии 57,3 1,3 МПа

ключевые слова: гидродинамический кавитатор, динамическая вязкость, кавитационная обработка, прочность при сжатии, цементно-водная суспензия.

Martyntsev Volodymyr, Postgraduate Student, Department of Machinery and Equipment Manufacturing Processes, Kyiv National University of Construction and Architecture, Ukraine, e-mail: snork12345@ukr.net, ORCID: http://orcid.org/0000-0002-4564-0250

Guzii Sergii, PhD, Senior Researcher, V. D. Glukhozsky Scientific Research Institute for Binders and Materials, Kyiv National University of Construction and Architecture, Ukraine, e-mail: sguziy@ukr.net, ORCID: http://orcid.org/0000-0003-0147-5035

Nazarenko Ivan, Doctor of Technical Sciences, Professor, Department of Machinery and Equipment Manufacturing Processes, Kyi National University of Construction and Architecture, Ukraine, e-mail i_nazar@i.ua, ORCID: https://orcid.org/0000-0002-1888-3687

Glyva Valentyn, Doctor of Technical Sciences, Professor, Department of Civil and Industrial Safety, National Aviation University, Kyiv, Ukraine, e-mail: larlevch@ukr.net, ORCID: http://orcid.org/00000003-1257-3351

Guzii Olena, Technician, V. D. Glukhovsky Scientific Research Institute for Binders and Materials, Kyiv National University of Construction and Architecture, Ukraine, e-mail: guzii.elena777@gmail.com, ORCID: http://orcid.org/0000-0001-9618-2950 